\title{
Effect of Emulsifier Diacetyl Tartaric Acid Ester of Mono- and Diglycerides (DATEM) and Enzyme Transglutaminase on Quality Characteristics of Rice Bran Croissants
}

\author{
Wan Zunairah Wan-Ibadullah ${ }^{\mathrm{a}^{*}}$, Aw Ying Hong ${ }^{\mathrm{a}}$, M. A. R. Nor-Khaizura ${ }^{\mathrm{a}}$, Nor \\ Afizah Mustapha ${ }^{\text {, }}$ Z. A. Nur Hanani ${ }^{b}$, Mohammad Rashedi Ismail-Fitry ${ }^{b}$, And \\ Anis Shobirin Meor Husin ${ }^{b}$ \\ ${ }^{a}$ Department of Food Science, Faculty of Food Science and Technology, Universiti Putra Malaysia, 43400 \\ Serdang, Selangor, Malaysia \\ ${ }^{\mathrm{b}}$ Department of Food Technology, Faculty of Food Science and Technology, Universiti Putra Malaysia, 43400 \\ Serdang, Selangor, Malaysia \\ ${ }^{*}$ Corresponding author \\ wanzunairah@upm.edu.my \\ TEL: +60389468352
}

Received: 3 August 2018; Published online: 24 February 2021

\begin{abstract}
Rice bran (RB) is a good source of dietary fibre. Addition of rice bran into croissant interferes with the gluten formation of dough and hence affect the physicochemical properties of croissant. The effect of RB addition on physicochemical properties of croissant were determined by using $0 \%, 10 \%$ and $15 \%$ RB. Besides, additives such as emulsifiers and enzymes can be used in pastry to enhance the physicochemical properties of croissant. Diacetyl tartaric acid ester of mono-diglycerides (DATEM) and transglutaminase (TGase) were used respectively on $0 \%, 10 \%$ and $15 \%$ RB to investigate the effect of such additives on physicochemical properties of croissant. Increased \% RB and DATEM, produced a significant decrease in specific volume, together with a significant increase in colour, hardness and chewiness. With increased \% RB, TGase caused significant increase in colour, hardness and chewiness but significant decrease in specific volume. The overall moisture sorption isotherm curves of the croissant belong to the Type III isotherm, also known as Flory-Huggins Isotherm (J-shaped). The critical $\mathrm{a}_{w}$ obtained from the Guggenheim-Anderson-de Boer (GAB) equation showed that the shelf life of croissants were not positively impacted by the addition of DATEM and TGase and the addition of RB did not cause any significant positive effects on quality characteristics of croissants.
\end{abstract}

Keywords: Rice bran(RB); DATEM; TGase; Physicochemical properties; Moisture sorption isotherm

\section{Introduction}

Rice bran is a by-product obtained from the rice milling industry. Due to its high nutrient content rice bran has potential to be used as food ingredient. However, the use of rice bran in food applications is limited mainly due to deterioration that is caused by enzymatic activity (Na- gendra Prasad, Sanjay, \& Khatokar M., 2011). Rice bran is an excellent source of total dietary fibre ranging from 20 - $51 \%$ (Saunders, 1990). In spite of its excellent nutrition value, a large amount of rice bran is discarded during the process of rice milling and is used as animal feed and sells at considerably low prices (McKee \& Latner, 2000). 


\section{Nomenclature}

DATEM diacetyl tartaric acid ester of mono and diglycerides

fwb flour weight basis
$\mathrm{RB}$ rice bran

TGase Transglutaminase
Recently, the focus of interest has been on the development of food products from by-products or wastes and other underutilised agricultural (Issara \& Rawdkuen, 2016; Sharma, Srivastava, \& Saxena, 2015). Addition of rice bran to a wide range of products will contribute to the development of new functional foods and fulfil the customers' expectations. The croissant is a layered bakery product, so named for its crescent shape. It is made of yeast-leavened dough, layered with butter, rolled and folded several times in succession, then cut into a triangle and rolled up like a scroll so that the centre bulges and the ends taper out. Dietary fibre is considered a critical ingredient in food products particularly in pastry products. However, fibre has been known to alter the texture, volume and shelf life of yeastleavened products. A study done by Ghufran Saeed, Arif, Ahmed, Ali, and Shih (2009) also investigated the impact of rice bran on the rheological parameters of dough. Based on the findings of the study, it was clear that adding hydrophobic rice bran to wheat had a negative impact on the mixture, leading to inferior performance in dough development and lower water absorption capacity. The physical properties of fibre including water holding, and swelling capacity that may interfere the interaction between starch and gluten network, resulting in poor dough development (Collar, Santos, \& Rosell, 2007). In high fibre bread, the addition of hydrocolloids provide various functional properties by controlling the water molecule's mobility, thus affecting the dough rheology, dough development and gas retention (Peressini, Pin, \& Sensidoni, 2011). Furthermore, additives with functional property (emulsifiers, antioxidants, acid or enzyme) can be used for quality improvement in pastry products.
DATEM functions as a dough strengthener that mainly interacts with gluten proteins, as a crumb softener or an anti-firming agent that can complex gelatinized starch (Gaupp \& Adams, 2014). Furthermore, enzymes have been considered as good alternatives for use in baking processes. Transglutaminase clearly has great potential as an additive to both white and wholemeal flour croissant doughs. TGase addition generally resulted in stronger dough properties, but superior handling properties were observed especially at lower addition levels (Basman, Koksel, \& Ng, 2002).

The present work aimed to evaluate the effect of addition of DATEM and TGase on physicochemical properties and shelf life of croissant with added RB. RB is considered as a good source of dietary fiber. However, the addition of RB may give various detrimental effects on dough handling and croissant quality characteristics. Therefore, food additives such as emulsifiers and enzymes are used to overcome this problem. DATEM and transglutaminase were added to increase the dough strength and volume. Furthermore, the optimal combination of RB, DATEM and TGase on quality of croissant in terms of quality characteristics also has been studied.

\section{Materials and Methods}

\subsection{Ingredients of croissant}

The ingredients used in preparation of croissants were wheat flour, salt, castor sugar, milk powder, yeast, butter, pastry margarine and eggs, which were purchased at local market. DATEM was obtained from Zhentong Food Technology 
Co., Ltd (Henan, China). TGase was bought from Ajinomoto North America Inc. (Itasca, Illinois, U.S.A).The stabilized RB was purchased from Bob's Red Mill Natural Foods (Milwaukie, Oregon, U.S.A). The croissant formulations were shown in Table 1.

\subsection{Baking of croissant}

On a wheat flour basis, the following ingredients were used to produce croissants: $45.5 \%$ of wheat flour, $20.4 \%$ of pastry margarine, $20.4 \%$ of ice water, $2.4 \%$ of eggs, $1.8 \%$ of milk powder, 0.5 $\%$ of salt, $4.5 \%$ of castor sugar, $0.9 \%$ of yeast, $3.6 \%$ of butter, $0.4 \%$ of DATEM and $0.4 \%$ of TGase. Wheat flour which contained $11.5 \%$ of moisture, $0.53 \%$ of ash, $12 \%$ of protein, and 31.2 $\%$ of gluten, was mixed thoroughly with castor sugar, milk powder and yeast using cake mixer (Taiwan Cake Mixer B5, Taiwan). Whole eggs, ice water, butter and salt were then added and mixed. The dough was sheeted on a table to a rectangular shape and covered with wet cloth, and proved in chiller for 30 mins. The dough was then sheeted to a wider and longer shape, by using a roller, and the pastry margarine was placed in the middle of the dough, given 3 -folds and then further proofed in chiller $\left(7^{\circ} \mathrm{C}\right)$ for 20 mins. The rolled pieces were put on a baking tray and left to proof for 60 mins, then baked at $190{ }^{\circ} \mathrm{C}$ for 15 minutes.

\subsection{Physicochemical analysis}

\section{Colour measurement}

Colour analysis was conducted to assess the colour of croissant the crust using a Chroma meter model CR-410 (Konika Minolta Inc, Osaka, Japan), calibrated with a white reference plate which is the standard for reflectiveness. Colour parameters were expressed as L* (lightness/darkness), $\mathrm{a}^{*}$ (redness/greenness) and $\mathrm{b}^{*}$ (yellowness/blueness).

\section{Specific volume analysis}

Specific volume analysis was conducted to determine the volume of croissant the using rapeseed displacement process according to the 10-05 method (AACC, 2000); green beans were used instead of rapeseeds. The green beans displaced by the croissant were collected and their volume measured $\left(\mathrm{cm}^{3}\right)$. The weight of croissant $(\mathrm{g})$ was obtained by using an electronic weighing balance SPO 61 (Scaltec, Germany). Specific volume was also calculated (volume divided by weight).

\section{Texture profile analysis}

Texture profile analysis was conducted by using a Texture Analyser TA.XT2i (Stable Micro Systems Ltd., Surrey, UK) provided with a SMS $\mathrm{P} / 75$ probe, that is a $75 \mathrm{~mm}$ diameter cylindrical probe and the strain applied was $50 \%$. The pretest speed was $1.00 \mathrm{~mm} / \mathrm{s}$, test speed was 5.00 $\mathrm{mm} / \mathrm{s}$, post-test speed was $5.00 \mathrm{~mm} / \mathrm{s}$ and the trigger force was $5.0 \mathrm{~g}$. The hardness, springiness and chewiness were the main factors evaluated in all croissant formulations (Boukid et al., 2018).

\section{Water activity}

The water activity of dough and crackers were measured using Water Activity Analyser (AquaLab 3TE, Pullman, USA). Each sample was transferred into a chamber (filled to quarter capacity). The chamber was then inserted into the analyser and the measurements started. The temperature of the water activity analyser ranged from 24 to $25^{\circ} \mathrm{C}$ and it took the device 15 mins to get a stable value.

\section{Moisture content}

The moisture content of croissant was measured using Moisture Analyser MA 35 (Sartorius, Germany). Each sample was transferred onto an aluminium sample pan. The pan was then inserted into the analyser and the measurements started. It took 15 mins for the device to get a constant weight. The temperature used in the analyser was $95{ }^{\circ} \mathrm{C}$.

\subsection{Analyses of crude protein and crude fat}

The analyses of moisture, crude protein $(\mathrm{N}$ - 6.25) were conducted using the standard micro-Kjeldahl method (AOAC Method 960.52). 
Quality characteristics of rice bran croissant | SI29

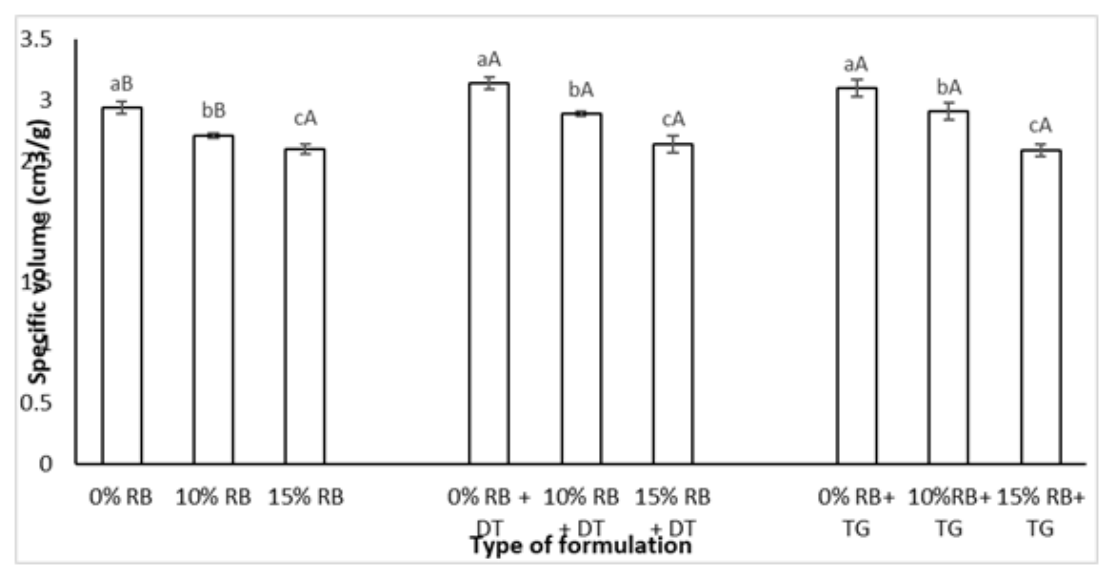

Figure 1: Specific volume - Effect of addition of RB on specific volume of croissant with and without addition of DATEM and TGase. ${ }^{a}$ indicates significant difference in specific volume compared among the same category (with DATEM/ with TGase/ without additive). ${ }^{b}$ indicates significant difference in specific volume compared among the same \% RB added.

Table 1: Croissant Formulation (\% by flour weight basis)

\begin{tabular}{llllllllll}
\hline Formulation (\%) & F1 & F2 & F3 & F4 & F5 & F6 & F7 & F8 & F9 \\
\hline Wheat flour & 45.5 & 45.5 & 45.5 & 45.5 & 35.5 & 35.5 & 30.5 & 30.5 & 30.5 \\
Rice bran & 0 & 0 & 0 & 10 & 10 & 10 & 15 & 15 & 15 \\
DATEM & 0 & 0.4 & 0 & 0 & 0.4 & 0 & 0 & 0.4 & 0 \\
TGase & 0 & 0 & 0.4 & 0 & 0 & 0.4 & 0 & 0 & 0.4 \\
Castor sugar & 4.5 & 4.5 & 4.5 & 4.5 & 4.5 & 4.5 & 4.5 & 4.5 & 4.5 \\
Milk powder & 1.8 & 1.8 & 1.8 & 1.8 & 1.8 & 1.8 & 1.8 & 1.8 & 1.8 \\
Yeast & 0.9 & 0.9 & 0.9 & 0.9 & 0.9 & 0.9 & 0.9 & 0.9 & 0.9 \\
Whole egg & 2.4 & 2.4 & 2.4 & 2.4 & 2.4 & 2.4 & 2.4 & 2.4 & 2.4 \\
Ice water & 20.4 & 20.4 & 20.4 & 20.4 & 20.4 & 20.4 & 20.4 & 20.4 & 20.4 \\
Salt & 0.5 & 0.5 & 0.5 & 0.5 & 0.5 & 0.5 & 0.5 & 0.5 & 0.5 \\
Butter & 3.6 & 3.6 & 3.6 & 3.6 & 3.6 & 3.6 & 3.6 & 3.6 & 3.6 \\
Pastry margarine & 20.4 & 20.4 & 20.4 & 20.4 & 20.4 & 20.4 & 20.4 & 20.4 & 20.4 \\
\hline
\end{tabular}


Crude fat were conducted using a Soxhlet extraction process with petroleum ether (AOAC Method 945.16) (AOAC, 2000).

\subsection{Dynamic Dewpoint Isotherm Method}

The Dynamic Dewpoint isotherms (DDIs) were obtained using the AquaSorp Isotherm Generator (Decagon Devices Inc., Pullman, WA, USA). Before the DDIs were obtained, the $\mathrm{a}_{w}$ dewpoint sensor was verified using two unsaturated aqueous salt solutions purchased from the instrument manufacturer, 13.41 molal $\mathrm{LiCl}(0.250 \pm 0.003$ $\left.\mathrm{a}_{w}\right)$ and 6.0 molal $\mathrm{NaCl}\left(0.760 \pm 0.003 \mathrm{a}_{w}\right)$. Working DDIs were obtained for each material (1 to $2 \mathrm{~g}$ in a stainless steel sample cup half filled) using the start from current $\mathrm{a}_{w}$ feature (AquaSorp firmware version ASIG 1.19, Decagon Devices, Pullman, WA, USA) with a $120 \mathrm{ml} / \mathrm{min}$ flow rate at $25{ }^{\circ} \mathrm{C}$. The adsorption and desorption sections of the working isotherm were obtained in duplicate, each on a different sample. The average DDI starting $\mathrm{a}_{w}$ and associated standard deviation for each material for both adsorption and desorption parts of the working isotherm are given in Table 2. Weight change at each $\mathrm{a}_{w}$ was converted to moisture content (\% $\mathrm{db}$ ) using the SorpTrac software (version 1.03.3, Decagon Devices, Pullman, WA, USA) using the initial measured moisture content value (Table 2).

\subsection{Statistical Analysis}

Statistical analyses were conducted using Minitab statistical software (Minitab 16, Minitab Inc, Pennsylvania). One-way analysis of variance (ANOVA) was performed to compare the data. The Tukey test was used to compare the average mean values obtained. The confidence limits used in this study were based on a level of $95 \%(\mathrm{P}<0.05)$.

\section{Results and Discussion}

\subsection{Colour measurement}

The surface colour is an essential attribute of yeasted pastry, and contributes to consumer preference. A brown crust is caused by a nonenzymatic browning reaction (Maillard type) between amino acids and reducing sugars (Kent \& Evers, 1994). Based on Table 3, there were no significant difference $(\mathrm{P}>0.05)$ observed in lightness, redness and yellowness on crust of croissant with the addition of $10 \%$ and $15 \%$ RB respectively. Addition of RB was expected to decrease the crust lightness but in this study, it showed no significant changes. When DATEM and TGase were used alone respectively, they decreased the lightness significantly. At $10 \%$ and $15 \%$ RB addition, DATEM and TGase both showed significant reduction $(\mathrm{P}<0.05)$ in lightness as compared to those with $\mathrm{RB}$ addition but without additives. The lower $\mathrm{L}^{*}$ crust values can be attributed to Maillard browning (Breeding \& Beyer, 2000). This could be due to increased amino acids available for Maillard reaction when the DATEM and TGase were used together with increased \% RB as RB, DATEM and TGase are proteins. The $a^{*}$ value increased with the increased RB. This could be due to the fine bran presence that produce darker yellowish color of the crumb (PopovRaljic, Mastilovic, Lalicic-Petronijevic, \& Popov, 2009).

\subsection{Specific volume}

Based on Figure 1, there were significant reduction $(\mathrm{P}<0.05)$ in specific volume with increase $\%$ of $\mathrm{RB}$. The reduction may be attributed to the higher level of gluten present in wheat flour compared to composite blends which could not be properly stretched by carbon dioxide $\left(\mathrm{CO}_{2}\right)$ gas during fermentation and proofing (Oladunmoye, Akinoso, \& Olapade, 2010). The decrease in croissant specific volume might be due to the high water absorption by the rice bran and the reduced air entrapment, resulting in heavier but smaller dough (higher weight but lower volume). When DATEM was used solely, the specific volume was significantly higher $(\mathrm{P}<0.05)$ compared 
to that where DATEM worked with $10 \%$ and $15 \%$ $\mathrm{RB}$ respectively. Rogers and Hoseney (1983) reported that addition of DATEM improved the loaf volume of wheat bread. The positive effect on bread volume of emulsifiers is caused by their dough strengthening properties by forming liquid films with a lamellar structure in the interphase between the gluten strands and the starch (Stampfli \& Nersten, 1995). Emulsifiers such as DATEM, with amphiphilic structure and properties, will increase the strength of the dough by interacting with hydrophobic regions of the gluten proteins, forming hydrogen bonds with the amino groups of glutamine (Azizi \& Rao, 2004; Gomez et al., 2004; Stampfli \& Nersten, 1995). Such factors would contribute to improved gas retention, better texture and increased volume of baked product (Chin, Goh, Rahman, \& Hashim, 2007). When TGase was used alone, it showed significant higher $(\mathrm{P}<0.05)$ specific volume compared to those which TGase used together with RB. The higher specific volume might due to the effect of TGase on the rheological behaviour whereby the TGase transforming weak gluten into a stronger one (Basman et al., 2002). Similar results also reported by Koksel, Ozay, K. W. Ng, and F. Steffe (2001). Gerrard et al. (1998) suggested that TGase alters the structure of the gluten proteins by crosslinking in dough development. Those could be either disulphide linkages, formed through oxidative processes or other covalent crosslinks. Based on Table 3, it can be observed that the specific volume significantly decreased $(\mathrm{P}<0.05)$ when TGase worked with increased \% RB. Basman et al. (2002) reported that TGase catalyse the formation of nondisulphide covalent crosslinks between peptidebound glutaminyl residues and $\varepsilon$-amino groups of lysine residues in protein, thereby decreasing the protein aggregates in the gluten network. Moreover, TGase yield intra and intermolecular $\varepsilon-\mathrm{N}-(\gamma$-glutamyl)-lysine crosslinks between proteins reinforcing gluten network, thereby increasing dough strength and tenacity (Joye, Lagrain, \& Delcour, 2009) and decreasing the specific volume.

\subsection{Textural properties}

Based on Table 4, there were no significant changes in hardness of croissant with increased $\%$ of RB $(\mathrm{P}>0.05)$. Besides, increased \% RB also did not show any significant changes in springiness of croissant. Other than that, there was significant increase $(\mathrm{P}<0.05)$ in chewiness with addition of $15 \%$ RB. This can explain by higher proportion of $\mathrm{RB}$ added contributed to the chewiness of croissant. As rice bran is an excellent source of fibre (Saunders, 1990), due to its water binding capacities, fibre inhibits water loss during storage and prevents staling that affects crumb firmness (Walter, 2014). The fact that firmness was impaired with increased fibre content may be associated with dietary fibre exhibiting increased water capacity, so water does not become available for gluten that is formed while kneading (Ranasalva \& Visvanathan, 2014) and cause increased croissant hardness and chewiness.

When DATEM was used alone, the hardness of croissant decreased significantly $(\mathrm{P}<0.05)$ compared to that where DATEM was used with $10 \%$ and $15 \%$ RB. According to Stampfli and Nersten (1995) and Sawa, Inoue, Lysenko, Edwards, and Preston (2009), the higher the amylose complexforming power of the emulsifier, the lower the initial bread crumb firmness. DATEM, which are monoacylglycerols with one stearic acid in the structure, might be expected to have a similar effect on bread firmness. Ribotta, Perez, Leon, and Anon (2004) have reported the reducing effect of DATEM on firmness for wheat breads and this can be explained by its capacity to aggregate gluten proteins, which create a gluten network that can improve the entrapment of air and result in better crumb texture. According to Gaupp and Adams (2014), in order for a given emulsifier to work properly in a dough system, it is necessary to consider the balancing of ingredients used to assist emulsifiers. Therefore, when DATEM worked together with RB, it is assumed that the emulsifier failed to interact with the protein in dough system due to disruption of ingredients after addition of fibre into the system. When TGase was used alone, the hardness of croissant was reduced significantly $(\mathrm{P}<0.05)$. This is in accordance to the study of 


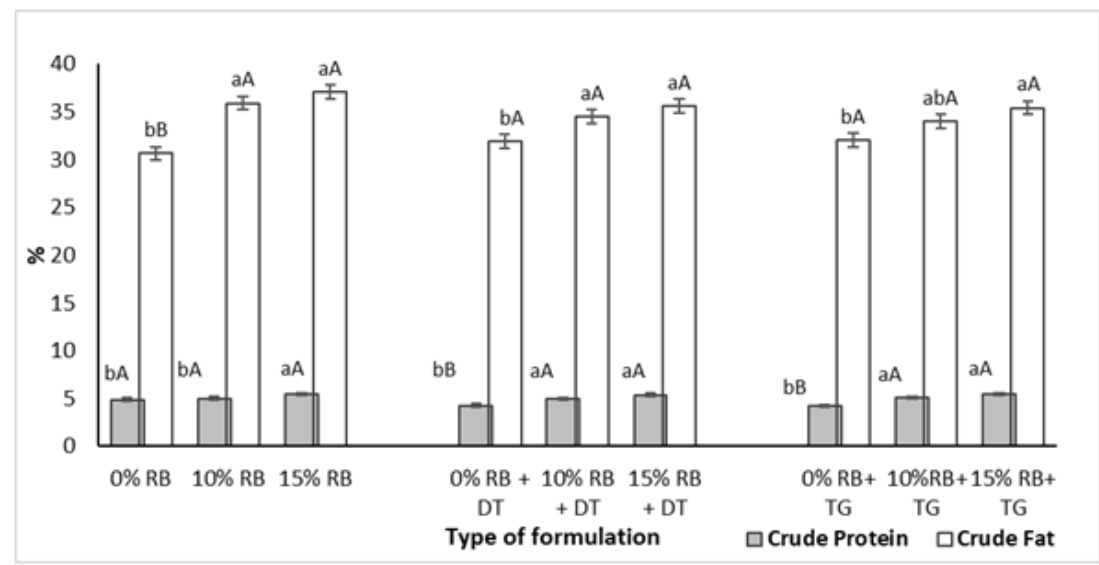

Figure 2: Crude protein and crude fat - Effect of addition of RB on crude protein and crude fat of croissant with and without addition of DATEM and TGase. ${ }^{a}$ indicates significant difference in crude protein and crude fat compared among the same category (with DATEM/ with TGase/ without additive). ${ }^{b}$ indicates significant difference in crude protein and crude fat compared among the same $\%$ RB added.

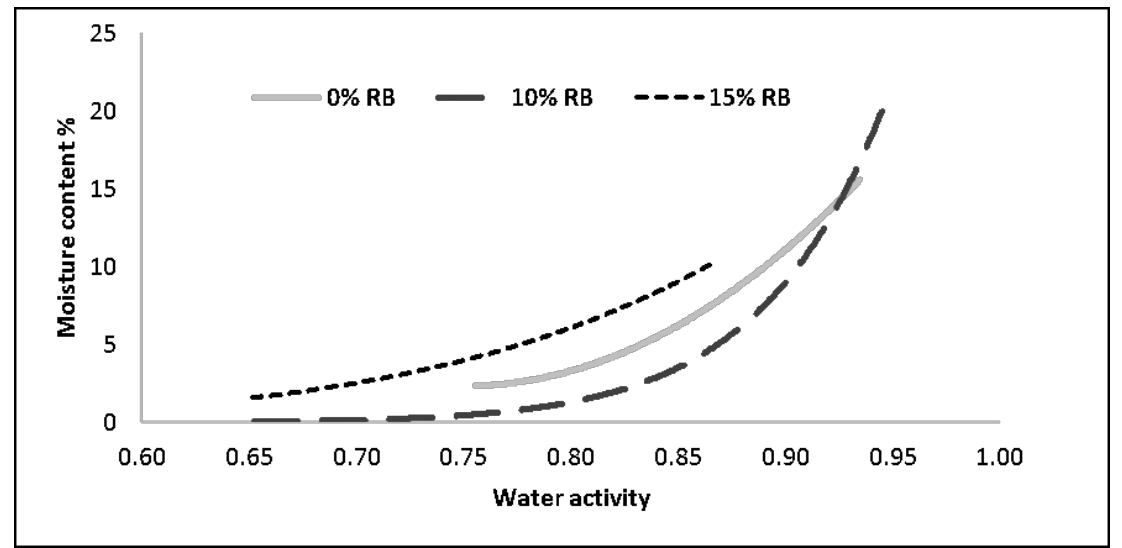

Figure 3: Moisture sorption isotherm without additives - Effect of addition of RB on moisture sorption isotherm without addition of additives 
Table 2: Moisture Content and Water Activity of Croissant Formulations

\begin{tabular}{lll}
\hline Formulation & Moisture content $(\% \mathrm{wb})$ & Water activity $\left(\mathrm{a}_{w}\right)$ \\
\hline 1 & 11.23 & 0.899 \\
2 & 15.85 & 0.823 \\
3 & 17.63 & 0.844 \\
4 & 9.1 & 0.867 \\
5 & 15.89 & 0.886 \\
6 & 13.18 & 0.818 \\
7 & 17.25 & 0.851 \\
8 & 14.72 & 0.815 \\
9 & 12.34 & 0.862 \\
\hline
\end{tabular}

Gerrard et al. (2001) who stated that in addition to the increased size, transglutaminase-treated croissants had a desirable flakiness and crumb texture. However, when TGase worked with increased \% RB, the hardness was significantly increased. This may be due to the quantity of fibre in dough increased but the water given into the dough system still remain constant, therefore resulting in hardening of final product. Besides, the quantity of TGase used might be not sufficient to catalyse the formation of non-disulphide covalent crosslinks between peptide-bound glutaminyl residues and $\varepsilon$-amino groups of lysine residues in protein in order to give softer texture. However, higher concentration of TGase like 1.0 $\%$ and $1.5 \%$ increased firmness of bread due to formation of a tough dough caused by excessive crosslinking (Basman et al., 2002).

\subsection{Crude protein and crude fat}

Based on Figure 2, crude protein increased significantly with $15 \% \mathrm{RB}$ addition but $10 \% \mathrm{RB}$ addition did not showed similar result. On the other hand, the addition of $10 \%$ and $15 \%$ RB both showed significant increase in crude fat of croissant respectively. Increase in crude protein content and crude fat is in agreement with study of O. Ameh, Gernah, and D. Igbabul (2013) and Farrell (1994) These authors had reported that rice bran is a good source of proteins, lipids, dietary fibre and minerals and could be an effective tool in supplementing lysine and methionine deficient foods such as wheat, maize and sorghum; thus serving as a tool to overcome the prevailing malnutrition problem.

When DATEM was added alone, it showed significant reduced $(\mathrm{P}<0.05)$ crude protein and increased crude fat. Decreased crude protein may due to the dough improving effect of emulsifiers seems to be related to their effect in reducing the repulsing charges between gluten proteins and thereby causing them to aggregate. This effect appears to be of particular importance in composite flours, as the wheat gluten has been diluted (Eduardo, Svanberg, \& Ahrne, 2016). When DATEM worked with $10 \%$ and $15 \% \mathrm{RB}$, there was a significant increase $(\mathrm{P}<0.05)$ in crude fat. This was also in agreement with study of O. Ameh et al. (2013) reported that there was increase of crude fat with increased level of RB supplementation.

When TGase was used solely, it showed significant lower $(\mathrm{P}<0.05)$ crude protein value. The results are in accordance with those found by Marco and Rosell (2008) who reported that free amino group of protein in samples significantly decreased with the addition of TGase. The extent of TGase catalyzed reaction was also confirmed by Huang et al. (2010) who observed a progressive decrease in the amount of free amino groups. According to Gujral and Rosell (2004), this could be because of involvement of amino acids groups of protein in the cross-linking reaction, and this change from free to total amino groups in terms of their concentrations. Higher crude protein value obtained when TGase was used with increased \% RB could be explained by 
SI34 | Wan-Ibadullah et al.

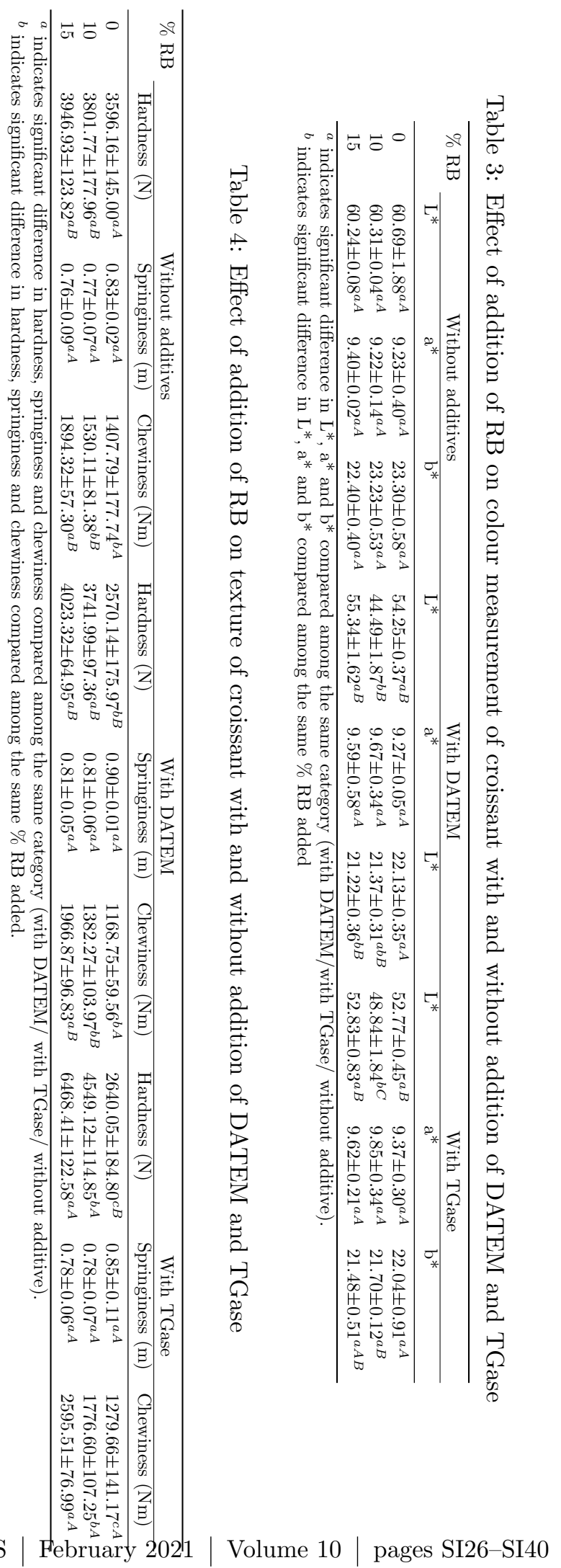


the protein reducing effect of TGase cancelled off with the addition of RB as RB is a good source of protein. There was a significant increase $(\mathrm{P}<0.05)$ in crude fat when TGase worked with $10 \%$ and $15 \%$ RB. This was due to the addition of RB into the croissant as processed RB is a good source of fat (Bhosale \& Vijayalakshmi, 2015).

\subsection{Moisture sorption isotherm}

It was found that the isotherm curves for the formulations with increased \% RB without any additives were all belong to Type III (J-shaped) isotherm (Figure 3), which also known as the Flory-Huggins isotherm. Moisture gain is very low up to the point where the crystals begin to dissolve in the absorbed water at the surface of crystal (Barbosa-Cánovas, Fontana, Schmidt, \& Labuza, 2008). As compared to $0 \% \mathrm{RB}$ addition, $10 \% \mathrm{RB}$ addition showed a moisture migration towards lower moisture content while $15 \%$ $\mathrm{RB}$ shifted the isotherm curve to a higher moisture content. Plasticization is not easy for carbohydrates due to their internal bonding structure that consists lots of hydrogen bonding. High temperature and moisture are required for gelatinization to open up structure to adsorption. Carbohydrates that have more hydrogen bonds and more open chains resulting in higher water holding capacity (Barbosa-Cánovas et al., 2008) can be observed in $15 \% \mathrm{RB}$ addition as higher $\% \mathrm{RB}$ contains higher fibre.

Based on Figure 4, the addition of DATEM into the formulations showed similar isotherm curves which were also categorized as a Type III (J-shaped) isotherm (Brunauer, 1945). When DATEM was used with the RB increased to 10 $\%$, the isotherm shifted upwards to a higher moisture content. However, when RB increased to 15 $\%$, the isotherm shifted downwards to a lower moisture content. DATEM as an emulsifier contains both hydrophilic and hydrophobic parts. According to Barbosa-Cánovas et al. (2008), the -OH groups on the glycerol will absorb moisture but the hydrophobic interactions between individual molecules block the moisture absorption. Hence, DATEM caused inconsistent moisture migration and unable to stabilize the moisture con- tent, which eventually affect textural properties and the shelf life of the product.

The addition of TGase into the formulations showed similar isotherm curves which were also categorized as a Type III (J-shaped) isotherm (Figure 5). According to Barbosa-Cánovas et al. (2008), proteins have plasticizing nature, resulting in increased availability of all polar groups. Heating at high temperatures generally increases adsorption. Therefore, with the addition of 15\% RB and enzyme TGase, the adsorption curve was the steepest. When the $\%$ of RB increased, TGase shifted the curve downwards to a higher moisture content. Bread staling increased by TGase addition, and affected specially to hardness, chewiness and gumminess (Caballero, Gomez, \& Rosell, 2007). The affinity to water promoted by TG in gluten (Gerrard et al., 1998) could also limit the water availability for starch and accelerate its retrogradation. The isotherm curves indicated that TGase did not help to stabilize the croissant.

\subsection{Critical water activity}

According to Carter, Galloway, Campbell, and Carter (2015), the water activity at which the inflection point in the DDI adsorption curve occurred was identified as the critical water activity (RHc) at the temperature of the isotherm. Due to its association with glass transition, this $\mathrm{RHc}$ has been identified as the critical water activity level for the loss of stability in amorphous powders. The RHc gives direct information about the maximum allowed relative vapour pressure for storage of amorphous or partially amorphous food systems (Barbosa-Cánovas et al., 2008). They also indicate that at a constant storage temperature, the glass transition may occur because of water sorption if the storage relative vapour pressure exceed the critical values. Based on the results obtained (Figure 6), the RHc values decreased as the \% RB increased without addition of any additives. Besides, when $\%$ RB increased, both DATEM and TGase also showed a trend of decreasing RHc values. This indicated that with increased \% RB and addition of additives, the croissant can enter glass transition state at a lower water activity. The product 
SI36 | Wan-Ibadullah et al.

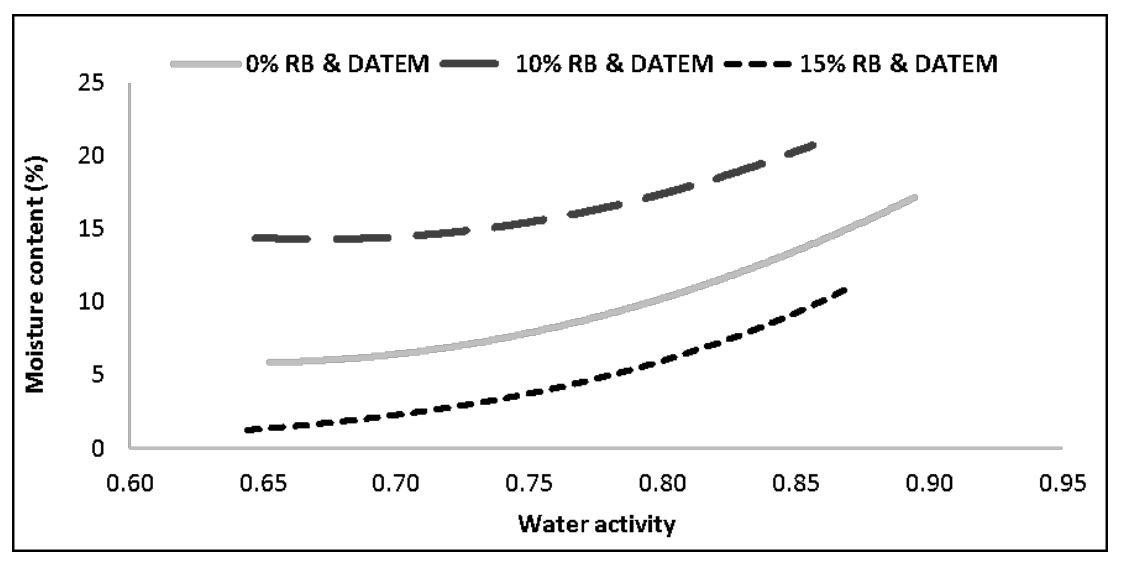

Figure 4: Moisture sorption isotherm DATEM - Effect of addition of RB on moisture sorption isotherm with addition of DATEM

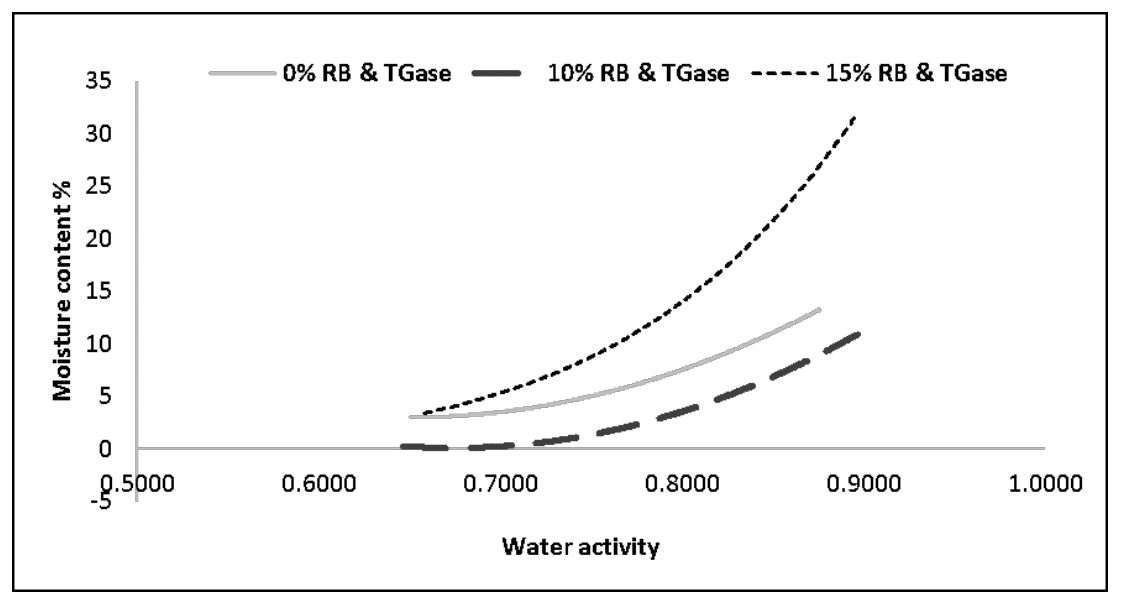

Figure 5: Moisture sorption isotherm TGase - Effect of addition of RB on moisture sorption isotherm with addition of TGase 


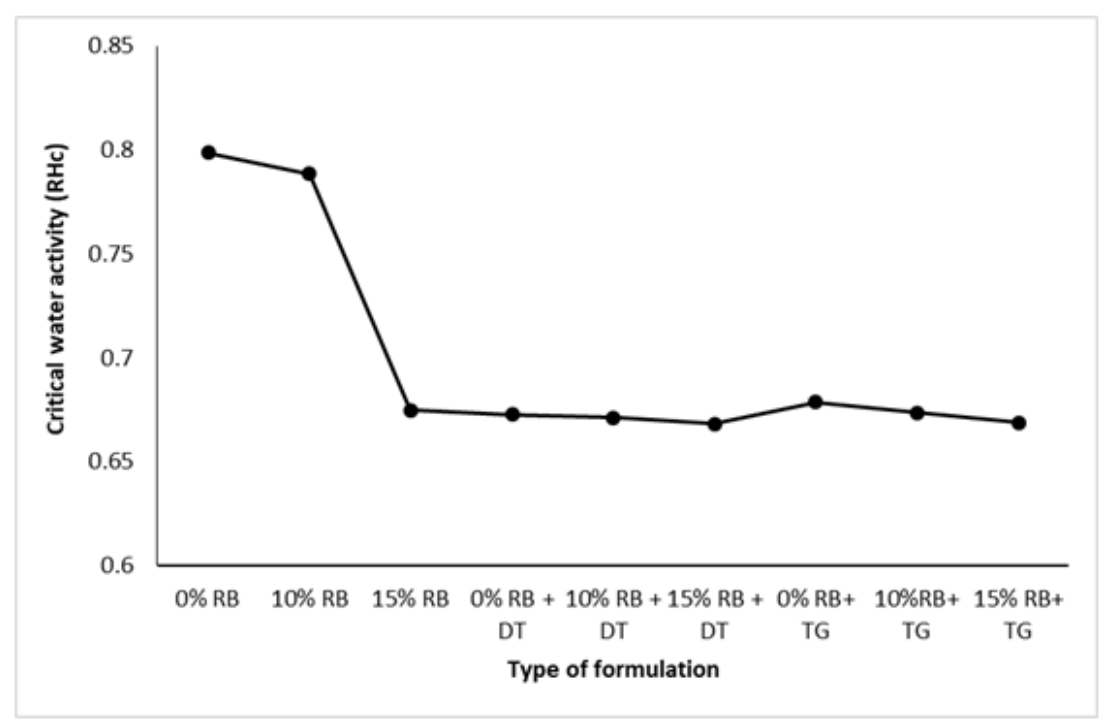

Figure 6: Critical water activity - Effect of addition of RB on critical water activity with and without addition of DATEM and TGase

can be transformed into a highly viscous, solidlike glass, 'frozen' over a temperature range and may exhibit only rotational motion and vibrations (Barbosa-Cánovas et al., 2008). Therefore, it can observed that the addition of DATEM and TGase both cannot help in stability of croissant.

\section{Conclusions}

It can be concluded that with increased \% RB without any additives, there was significant decreased specific volume, increased chewiness (only with $15 \% \mathrm{RB}$ ), and increased crude protein and crude fat content. When DATEM and TGase were used alone, they showed significant decreased lightness, increased specific volume and decreased hardness. They also decreased crude protein and increased crude fat significantly. When DATEM and TGase worked with increased \% RB, there was significant decreased lightness and specific volume, increased hardness, and increased chewiness. The moisture sorption isotherm curves of the croissant belong to the Type III isotherm, also known as Flory-Huggins Isotherm (J-shaped). The critical $\mathrm{a}_{w}$ obtained from the Guggenheim-Anderson-de Boer (GAB) equation showed that the shelf life of croissant were not positively impacted by the addition of DATEM and TGase. It can be concluded that DATEM and TGase did not provide any significant positive effect on quality characteristics of croissant with the addition of RB.

\section{Acknowledgements}

This work was supported by Geran Putra (Grant No. 9550600), which was awarded by the Universiti Putra Malaysia.

\section{References}

AACC. (2000). American association of cereal chemists, aacc. Approved Methods of the AACC. AACC International, Minnesota.

AOAC. (2000). Official methods of analysis (17th ed., method nos: 979.09, 920.39). washington, dc. Association of Official Analytical Chemists.

Azizi, M. H., \& Rao, G. V. (2004). Effect of surfactant gels on dough rheological characteristics and quality of bread. Critical Reviews in Food Science and Nutrition, 44(7-8), 545-552. doi:10.1080/10408690490489288 
Barbosa-Cánovas, G. V., Fontana, A., Schmidt, S. J., \& Labuza, T. (2008). Water activity in foods: Fundamentals and applications. doi:10.1002/9780470376454

Basman, A., Koksel, H., \& Ng, P. K. W. (2002). Effects of increasing levels of transglutaminase on the rheological properties and bread quality characteristics of two wheat flours. European Food Research and Technology, 215(5), 419-424. doi:10 . 1007/ s00217-002-0573-3

Bhosale, S., \& Vijayalakshmi, D. (2015). Processing and nutritional composition of rice bran. Current Research in Nutrition and Food Science, 3(1), 74-80. doi:10.12944/ CRNFSJ.3.1.08

Boukid, F., Carini, E., Curti, E., Bardini, G., Pizzigalli, E., \& Vittadini, E. (2018). Effectiveness of vital gluten and transglutaminase in the improvement of physicochemical properties of fresh bread. $L W T$ Food Science and Technology, 92. doi:10. 1016/j.lwt.2018.02.059

Breeding, C. J., \& Beyer, R. S. (2000). Food chemistry: Principles and applications. . In G. L. Christen \& J. S. Smith (Eds.), (Chap. Eggs, pp. 421-431). West Sacramento: Science Technology System.

Brunauer, S. (1945). The adsorption of gases and vapors. Physical adsorption, 1.

Caballero, P. A., Gomez, M., \& Rosell, C. M. (2007). Improvement of dough rheology, bread quality and bread shelf-life by enzymes combination. Journal of Food Engineering, 81(1), 42-53. doi:10.1016/j . jfoodeng.2006.10.007

Carter, B. P., Galloway, M. T., Campbell, G. S., \& Carter, A. H. (2015). The critical water activity from dynamic dewpoint isotherms as an indicator of crispness in low moisture cookies. Journal of Food Measurement and Characterization, 9(3), 463-470. doi:10 . 1007/s11694-015-9254-3

Chin, N. L., Goh, S. K., Rahman, R. A., \& Hashim, D. M. (2007). Functional effect of fully hydrogenated palm oil-based emulsifiers on baking performance of white bread. International Journal of Food Engineering, 3(3). doi:10.2202/1556-3758.1196
Collar, C., Santos, E., \& Rosell, C. M. (2007). Assessment of the rheological profile of fibreenriched bread doughs by response surface methodology. Journal of Food Engineering, 78(3), 820-826. doi:10.1016/j.jfoodeng. 2005.11 .026

Eduardo, M., Svanberg, U., \& Ahrne, L. (2016). Effect of hydrocolloids and emulsifiers on the shelf-life of composite cassava-maizewheat bread after storage. Food Science 83 Nutrition, 4(4), 636-644. doi:10.1002/fsn3. 326

Farrell, D. J. (1994). Utilization of rice bran in diets for domestic-fowl and ducklings. Worlds Poultry Science Journal, 50(2), 115-131. doi:10.1079/WPS19940012

Gaupp, R., \& Adams, W. (2014). Diacetyl Tartaric Esters of Monoglycerides (DATEM) and Associated Emulsifiers in Bread Making. In Emulsifiers in food technology (Chap. 6, pp. 121-146). doi:10 . 1002/ 9781118921265 . ch6. eprint: https : / / onlinelibrary.wiley.com/doi/pdf/10.1002/ 9781118921265.ch6

Gerrard, J. A., Fayle, S. E., Wilson, A. J., Newberry, M. P., Ross, M., \& Kavale, S. (1998). Dough properties and crumb strength of white pan bread as affected by microbial transglutaminase. Journal of Food Science, 63(3), 472-475. doi:10.1111/j.1365-2621. 1998.tb15766.x

Gerrard, J. A., Newberry, M. P., Ross, M., Wilson, A. J., Fayle, S. E., \& Kavale, S. (2001). Pastry lift and croissant volume as affected by microbial transglutaminase. Journal of Food Science, 65(2), 312-314. doi:10.1111/ j.1365-2621.2000.tb15999.x

Ghufran Saeed, S. M., Arif, S., Ahmed, M., Ali, R., \& Shih, F. (2009). Influence of rice bran on rheological properties of dough and in the new product development. Journal of food science and technology, 46(1), 62.

Gomez, M., del Real, S., Rosell, C. M., Ronda, F., Blanco, C. A., \& Caballero, P. A. (2004). Functionality of different emulsifiers on the performance of breadmaking and wheat bread quality. European Food Research and Technology, 219(2), 145-150. doi:10.1007/ s00217-004-0937-y 
Gujral, H. S., \& Rosell, C. M. (2004). Functionality of rice flour modified with a microbial transglutaminase. Journal of Cereal Science, 39(2), 225-230. doi:10.1016/j.jcs. 2003.10.004

Huang, W., Li, L., Wang, F., Wan, J., Tilley, M., Ren, C., \& Wu, S. (2010). Effects of transglutaminase on the rheological and mixolab thermomechanical characteristics of oat dough. Food Chemistry, 121(4), 934-939. doi:10.1016/j.foodchem.2010.01.008

Issara, U., \& Rawdkuen, S. (2016). Rice bran: A potential of main ingredient in healthy beverage. International Food Research Journal, $23(6)$.

Joye, I. J., Lagrain, B., \& Delcour, J. A. (2009). Use of chemical redox agents and exogenous enzymes to modify the protein network during breadmaking - a review. Journal of Cereal Science, 50(1), 11-21. doi:10. 1016/j.jcs.2009.04.001

Kent, N. L., \& Evers, A. D. (1994). Technology of cereals: An introduction for students of food science and agriculture. Woodhead Publishing.

Koksel, H., Ozay, D., K. W. Ng, P., \& F. Steffe, J. (2001). Effects of transglutaminase enzyme on fundamental rheological properties of sound and bug-damaged wheat flour doughs. Cereal Chemistry - Cereal Chem, 78, 26-30. doi:10.1094/CCHEM.2001.78.1. 26

Marco, C., \& Rosell, C. M. (2008). Effect of different protein isolates and transglutaminase on rice flour properties. Journal of Food Engineering, 84(1), 132-139. doi:10. 1016/j.jfoodeng.2007.05.003

McKee, L. H., \& Latner, T. A. (2000). Underutilized sources of dietary fiber: A review. Plant Foods for Human Nutrition, 55(4), 285-304. doi:10.1023/A:1008144310986

Nagendra Prasad, M. N., Sanjay, K., \& Khatokar M., S. (2011). Health benefits of rice bran a review. Journal of Nutrition \& Food Sciences, 01. doi:10.4172/2155-9600.1000108

O. Ameh, M., Gernah, D., \& D. Igbabul, B. (2013). Physico-chemical and sensory evaluation of wheat bread supplemented with stabilized undefatted rice bran. Food and
Nutrition Sciences, 4, 43-48. doi:10.4236/ fns.2013.49A2007

Oladunmoye, O., Akinoso, R., \& Olapade, A. (2010). Evaluation of some physicalchemical properties of wheat, cassava, maize and cowpea flours for bread making. Journal of Food Quality, 33, 693-708. doi:10.1111/j.1745-4557.2010.00351.x

Peressini, D., Pin, M., \& Sensidoni, A. (2011). Rheology and breadmaking performance of rice-buckwheat batters supplemented with hydrocolloids. Food Hydrocolloids, 25(3), 340-349. doi:10.1016/j. foodhyd.2010.06. 012

Popov-Raljic, J. V., Mastilovic, J. S., LalicicPetronijevic, J. G., \& Popov, V. S. (2009). Investigations of bread production with postponed staling applying instrumental measurements of bread crumb color. Sensors, 9(11), 8613-8623. doi:10 . 3390/ s91108613

Ranasalva, N., \& Visvanathan, R. (2014). Development of bread from fermented pearl millet flour. Journal of Food Processing and Technology, 5(5).

Ribotta, P. D., Perez, G. T., Leon, A. E., \& Anon, M. C. (2004). Effect of emulsifier and guar gum on micro structural, rheological and baking performance of frozen bread dough. Food Hydrocolloids, 18(2), 305-313. doi:10.1016/S0268-005X(03)00086-9

Rogers, D. E., \& Hoseney, R. C. (1983). Breadmaking properties of datem. Bakers Digest, 12-\&.

Saunders, R. M. (1990). The properties of rice bran as a food stuff. Cereal Foods World, 35, 632-662.

Sawa, K., Inoue, S., Lysenko, E., Edwards, N. M., \& Preston, K. R. (2009). Effects of purified monoglycerides on canadian short process and sponge and dough mixing properties, bread quality and crumb firmness during storage. Food Chemistry, 115(3), 884-890. doi:10.1016/j.foodchem.2009.01.010

Sharma, R., Srivastava, T., \& Saxena, D. C. (2015). Studies on rice bran and its benefits-a review. Int. J. Eng. Res. Appl, 5(5), 107-112. 
SI40 | Wan-Ibadullah et al.

Stampfli, L., \& Nersten, B. (1995). Emulsifiers in bread making. Food Chemistry, 52(4), 353-360.

Walter, T. (2014). Degradation of gluten in wheat bran and bread drink by means of a proline-specific peptidase. Journal of $\mathrm{Nu}$ trition \& Food Sciences, 04. doi:10.4172/ 2155-9600.1000293

IJFS | February $2021 \mid$ Volume $10 \mid$ pages SI26-SI40 